\title{
EDUKASI KESEHATAN DARING UNTUK MENINGKATKAN PENGETAHUAN DAN PERILAKU TENTANG PENCEGAHAN PENULARAN COVID 19 DI KECAMATAN LANGKE REMBONG MANGGARAI NTT
}

\author{
Angelina Roida Eka ${ }^{1 *}$, Lidwina Dewy Wea ${ }^{2}$, Bonavantura Nursi Nggarang ${ }^{3}$, \\ Maria Getrida Simon ${ }^{4}$, Aldegonda Fitri Jeharut ${ }^{5}$, Anastasia Badar ${ }^{6}$, Maria $^{3}$ \\ Helena Nai ${ }^{7}$, Rosalia D Padut ${ }^{8}$ \\ ${ }^{1-8}$ Universita Katolik Indonesia Santu Paulus Ruteng \\ Email Korespondensi: ajenngelina@yahoo.com
}

Disubmit: 18 Juni 2021

Diterima: 30 Juni 2021

DOI: https://doi.org/10.33024/jkpm.v5i2.4564

Diterbitkan: 01 Februari 2022

\section{ABSTRAK}

Sejak ditetapkan sebagai pandemik hingga kini corona viruse disease (COVID-19) telah menginfeksi 30 juta orang di seluruh dunia dan 1.7 Juta orang di Indonesia. Di Provinsi NTT orang dengan COVID-19 telah mencapai angka 16347 orang termasuk 1961 orang yang berasal dari Manggarai. World Health Organisation (WHO) merekomendasikan cara terbaik untuk terhindar dari penyakit ini adalah dengan melakukan pencegahan penularan yaitu mencuci tangan, memakai masker, dan menjaga jarak sosial dan fisik. Namun demikian masih banyak masyarakat yang tidak mematuhi panduan tersebut dan bahkan tidak peduli. Pengabdian masyarakat ini bertujuan untuk meningkatkan pengetahuan dan perilaku masyarakat di Manggarai khususnya kecamatan Langke Rembong tentang COVID-19. Pengabdian masyarakat ini dilakukan secara daring dengan menggunakan media Whatsapp. Sebanyak 160 orang yang bersedia untuk mengikuti kegiatan dibagi ke dalam 8 kelompok masing-masing berisikan 20 peserta. Kegiatan ini terdiri dari 3 pokok kegiatan yaitu (1)Pemberian edukasi tentang peningkatan imunitas fisik dan cara pencegahan penularan COVID-19 (2) Latihan mandiri edukasi tentang peningkatan imunitas fisik dan cara pencegahan penularan COVID-19 (3) Evaluasi setelah edukasi dan latihan mandiri. Hasil dari pengabdian masyarakat ini adalah bahwa terjadi peningkatan yang signifikan pada pengetahuan klien setelah dilakukan edukasi kesehatan secara online yaitu sebelum dilakukan rata-rata pengetahuan sebelum adalah 11,57 menjadi 17,23 setelah dilakukan. Selain itu terjadi juga peningkatan perilaku sebelum edukasi dari 16,23 menjadi 21,03. Hasil tersebut diharapkan menjadi saran bagi pemerintah dan tenaga kesehatan daerah untuk terus memberikan informasi tentang COVID-19 dan memotivasi masyarakat untuk melakukan perilaku pencegahan COVID-19 dan mengurangi penularan.

Kata Kunci: edukasi kesehatan, COVID-19, Pencegahan penularan

\section{ABSTRACT}

Since it was declared a pandemic, until now the corona viruse disease (COVID19) has infected 160 million people worldwide and 1.7 million people in Indonesia. In NTT Province, the number of people with COVID-19 has reached 16347 people including 1961 people who came from Manggarai regency. The 
World Health Organization (WHO) recommends that the best way to avoid this disease is to prevent transmission and improve physical health. However, there are still many people who do not comply with these guidelines and do not even care. This community service aims to increase the knowledge and behavior of the people in Mangarai about COVID-19. This community service is carried out online using Whatsapp. A total of 160 people who were willing to take part in the activity were divided into 8 groups Whatsapp which each containing 20 participants. This activity consists of 3 main activities, namely (1) Providing education about increasing physical immunity and ways to prevent transmission of COVID-19 (2) Self-training education on increasing physical immunity and ways to prevent transmission of COVID-19 (3) Evaluation after education and training independently. The result of this community service is that there is a significant increase in knowledge and behavior after online health education; The mean value of knowledge before the health education is 11.57 and increase to 17.23 after. The mean of behavior before health education is 16.23 and 21 , 03 afterward. These results are expected to be suggestions for the government and local health workers to continue to provide information about COVID-19 and motivate the public to take COVID-19 prevention behavior seriously to reduce COVID-19 transmission.

Key Words: Health education, COVID-19, transmission prevention

\section{PENDAHULUAN}

World Health Organisation (WHO) mengumumkan bahwa coronavirus disease 19 (COVID-19) yang disebabkan oleh Severe acute respiratory coronavirus 2 (SARS-CoV-2) sebagai pandemik pada bulan Maret 2020(WHO, 2020) Penyebaran COVID-19 yang cepat membuat masalah yang cukup signifikan terutama kematian. Corona virus Disease-19 (COVID-19) pertama kali ditemukan di China pada akhir Desember 2019 dan telah menyebar hingga ke 213 negara dan menginfeksi lebih dari 150 juta orang (Worldmeter, 2021). Penyebaran pandemik COVID-19 yang cepat menyebabkan masalah yang berhubungan dengan sosial, ekonomi, dan kesehatan. Untuk mencegah penyebaran COVID-19 WHO mengeluarkan cara pencegahan penularan seperti menjaga jarak fisik, mencuci tangan, memakai masker, dan isolasi mandiri (CDC, 2020; WHO, 2020). Hingga Juni 2021 di Indonesia orang dengan COVID-19 telah mencapai angka 1.7 juta kasus dengan angka kematian 49 ribu orang (Worldmeter, 2021) Kejadian COVID-19 telah tersebar di 33 provinsi di Indonesia termasuk Nusa Tenggara Timur yaitu 16 ribu kasus (Pos Kupang, 2020).

Tingginya prevalensi dan cepatnya penambahan angka kejadian dapat disebabkan oleh mudah menularnya COVID-19 dari manusia ke manusia. Penularan tersebut dapat terjadi khususnya pada orang yang kontak langsung dengan pasien COVID-19 atau lingkungannya. COVID-19 menular melalui media percikan batuk/bersin. Kelompok risiko yang rentan terhadap penularan COVID-19 adalah tenaga medis, kelompok lansia, ibu hamil, balita dan anak-anak, serta orang dengan penyakit kronis (CDC, 2020). Penelitian sebelumnya menjelaskan bahwa tingginya angka kejadian COVID-19 disebabkan oleh pengetahuan dan sikap masyarakat yang masih rendah terutama dalam mencegah penularan (Djalante et al., 2020; López-Bueno et al., 2020). Masyarakat masih menganggap remeh dan Mengabaikan protokol kesehatan. Hal ini pun terjadi pada masyarakat di Kabupaten Manggarai yang 
kemudian meningkatkan penularan COVID-19. Penelitian tentang faktorfaktor yang mempengaruhi ketaatan remaja di kabupaten Manggarai menemukan bahwa jenis kelamin, persepsi terhadap COVID-19, Pengetahuan, dan tanggung jawab sosial mempengaruhi ketaatan dalam melakukan protokol kesehatan (Ningsih et al., 2021). Melihat hal tersebut edukasi ini diberikan untuk meningkatkan pengetahuan dan perilaku pada masyarakat di Kabupaten Manggarai.

Kabupaten Manggarai berada di Provinsi Nusa Tenggara timur. Menurut informasi dari pemerintahan Kabupaten Manggarai hingga Mei 2021 terdapat 1961 kasus orang dengan COVID-19 di Manggarai dengan 8 klien meninggal (Pemkab Manggarai, 2021) . Kabupaten Manggarai dan Satgas COVID-19 telah melakukan upaya untuk mencegah penularan, tetapi menurut wawancara studi pendahuluan yang dilakukan terhadap 10 masyarakat di Kabupaten Manggarai mengenai pengetahuan tentang pencegahan COVID-19 didapatkan bahwa masyarakat masih melakukan aktivitas di luar rumah dan jarang memakai masker. Hal tersebut terutama karena terbatasnya informasi yang diterima dan adanya anggapan COVID-19 sebagai penyakit yang biasa saja. Studi pendahuluan tersebut mengindikasikan bahwa masih banyak masyarakat yang tidak mengerti tentang hal pentingnya menjaga jarak. Melihat hal tersebut, pemberian edukasi kepada masyarakat penting untuk meningkatkan pengetahuan dan juga perilaku. Pengabdian masyarakat ini diharapkan dapat meningkatkan pengetahuan dan mengubah perilaku masyarakat menjadi taat pada protokol kesehatan COVID-19.

Melawan pandemi COVID-19 dapat dilakukan meliputi upaya promotif, preventif, dan rehabilitatif. Upaya promotif dan preventif dilakukan dengan meningkatkan pengetahuan masyarakat tentang COVID-19, cara penularan, pencegahan dan pemutusan rantai penularan COVID-19. Hasil wawancara didapatkan informasi bahwa hingga saat ini belum ada upaya-upaya peningkatan imunitas fisik, kesehatan jiwa dan psikososial yang diterapkan dimasyarakat sebagai cara untuk melawan pandemi COVID-19. Minimnya informasi yang benar dan akurat sebagai bentuk edukasi masyarakat membuat masyarakat merasa ketakutan, cemas membentuk stigma negatif yang kuat bagi penderitanya. Kebutuhan masyarakat untuk tetap dapat memenuhi kebutuhan hidup sehari-hari menjadi hambatan dalam menerapkan aturan pemerintah untuk bekerja dari rumah saat ini sehingga kebanyakan masyarakat masih beraktivitas di luar. Selain itu sulitnya mendapatkan masker yang terstandar dengan harga terjangkau juga hand sanitizer membuat masyarakat masih belum menerapkan aturan pemerintah salah satunya memakai masker dan mencuci tangan atau menggunakan hand sanitizer. Melihat dari hal tersebut, maka pengabdi bermaksud untuk melakukan edukasi kesehatan untuk meningkatkan pengetahuan dan perilaku masyarakat selama pandemik COVID-19.

\section{MASALAH}

Kabupaten Manggarai berada di Provinsi Nusa Tenggara timur. Menurut informasi dari Dinkes NTT hingga saat ini sudah 41 kasus orang dengan COVID-19 di Manggarai dengan 1 klien meninggal. Kabupaten Manggarai dan Satgas COVID-19 telah melakukan upaya untuk mencegah penularan, tetapi menurut wawancara studi pendahuluan yang dilakukan terhadap 10 masyarakat di Kabupaten Manggarai mengenai pengetahuan tentang pencegahan COVID-19 didapatkan bahwa masyarakat masih melakukan 
aktivitas di luar rumah dan jarang memakai masker. Hal tersebut terutama karena terbatasnya informasi yang diterima dan adanya anggapan COVID-19 sebagai penyakit yang biasa saja. Studi pendahuluan tersebut mengindikasikan bahwa masih banyak masyarakat yang tidak mengerti tentang hal pentingnya menjaga jarak. Melihat hal tersebut, pemberian edukasi kepada masyarakat penting untuk meningkatkan pengetahuan dan juga perilaku. Pengabdian masyarakat ini diharapkan dapat meningkatkan pengetahuan dan mengubah perilaku masyarakat menjadi taat pada protokol kesehatan COVID-19

Lokasi Kegiatan

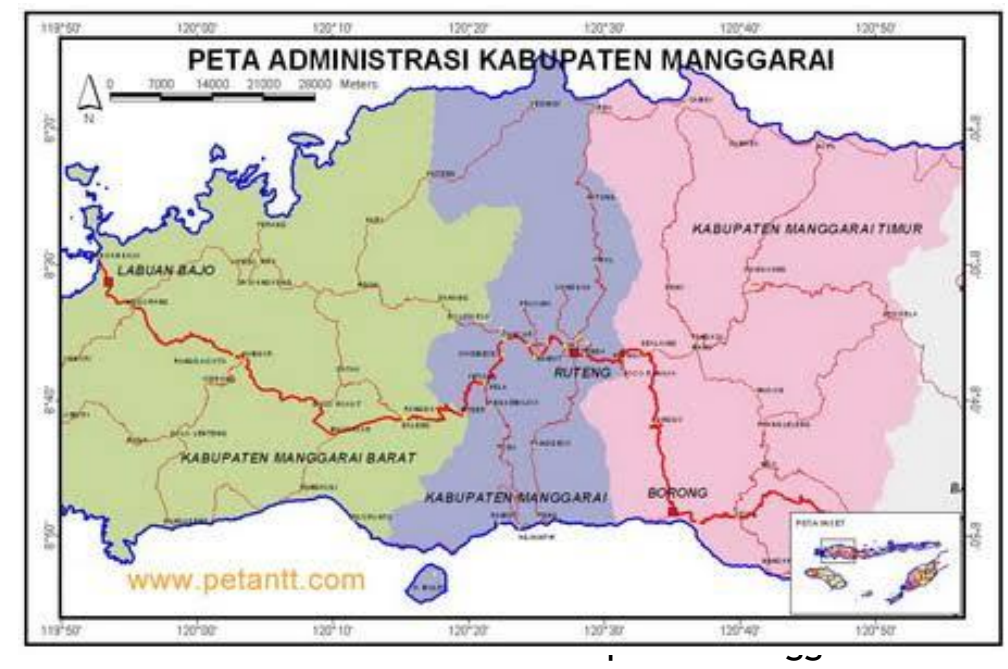

\section{METODE}

Pengabdian kepada masyarakat dilakukan secara daring melalui grup whatsapp terhadap 160 masyarakat yang terbagi dalam 8 grup whats app pada bulan Desember 2020 - Januari 2021. Program pemberdayaan masyarakat selama pandemik COVID-19 ini terdiri dari 3 kegiatan pokok yaitu (1)Pemberian edukasi tentang cara meningkatkan imunitas fisik dengan istirahat yang cukup 7 jam per hari, minum air yang 2L per hari, mengonsumsi sayur buah dan vitamin, berjemur pukul 9 pagi dan cara mencegah penularan COVID-19 dengan cara memakai masker, menjauhi kerumunan, mencuci tangan, membersihkan handphone, dan menjaga jarak fisik. (2) Latihan mandiri cara meningkatkan imunitas fisik mencegah penularan OCVID-19 dan cara mencegah masalah kesehatan jiwa dengan menerapkan perilaku meningkatkan kesehatan fisik selama COVID-19 (3) Peningkatan perilaku dan pengetahuan klien setelah diberikan edukasi. Adapun outcome yang diharapkan dari melakukan program pemberdayaan masyarakat ini yaitu Meningkatnya peran masyarakat dalam upaya meningkatkan imunitas fisik dan pencegahan penularan COVID-19 melalui edukasi yang diberikan pengabdi. Secara ringkas bentuk program dapat dilihat pada skema berikut ini 
Skema 1 - Bentuk Program Pengabdian Masyarakat

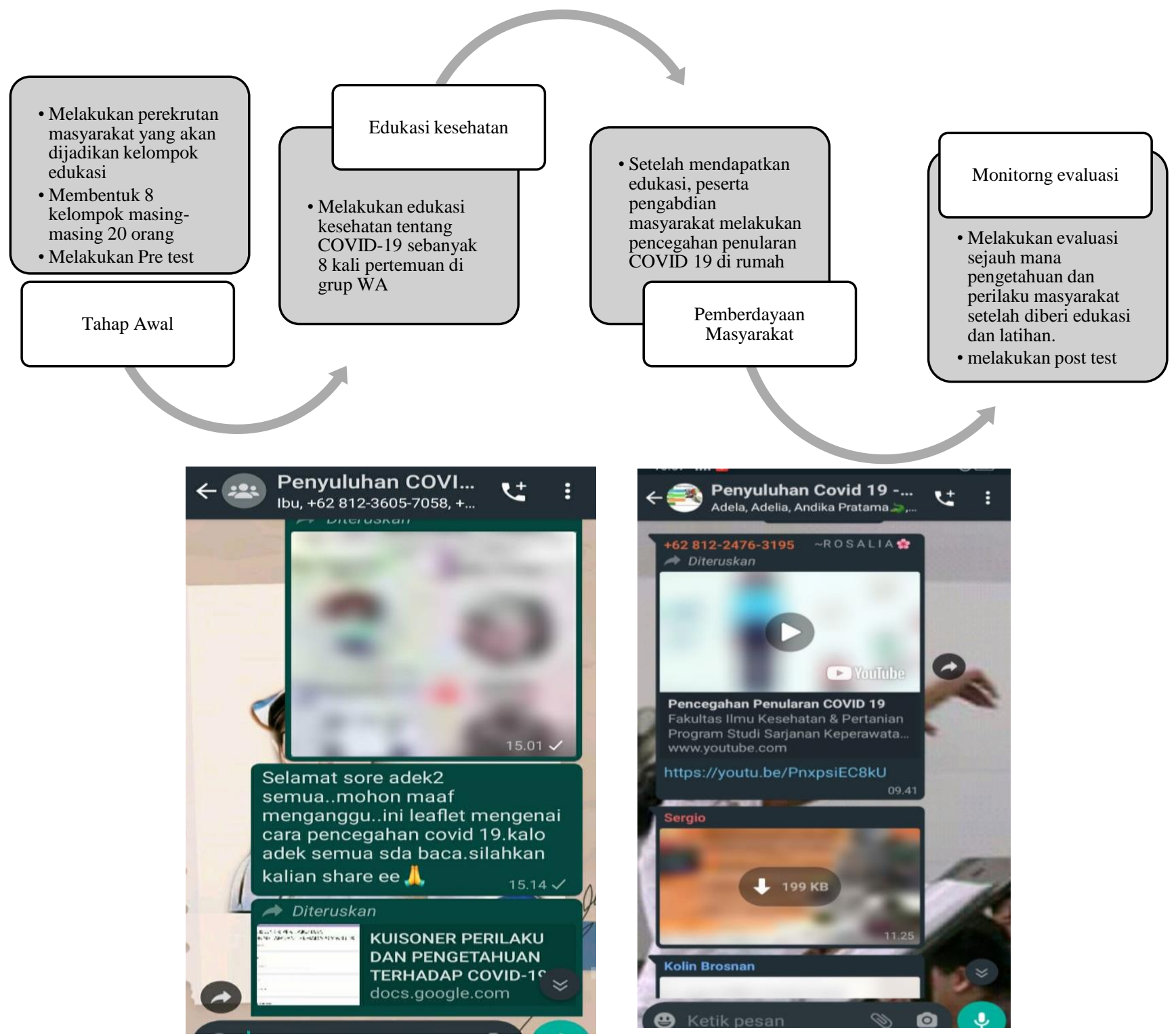

Gambar2. Foto Kegiatan Edukasi Melalui Grup WA 

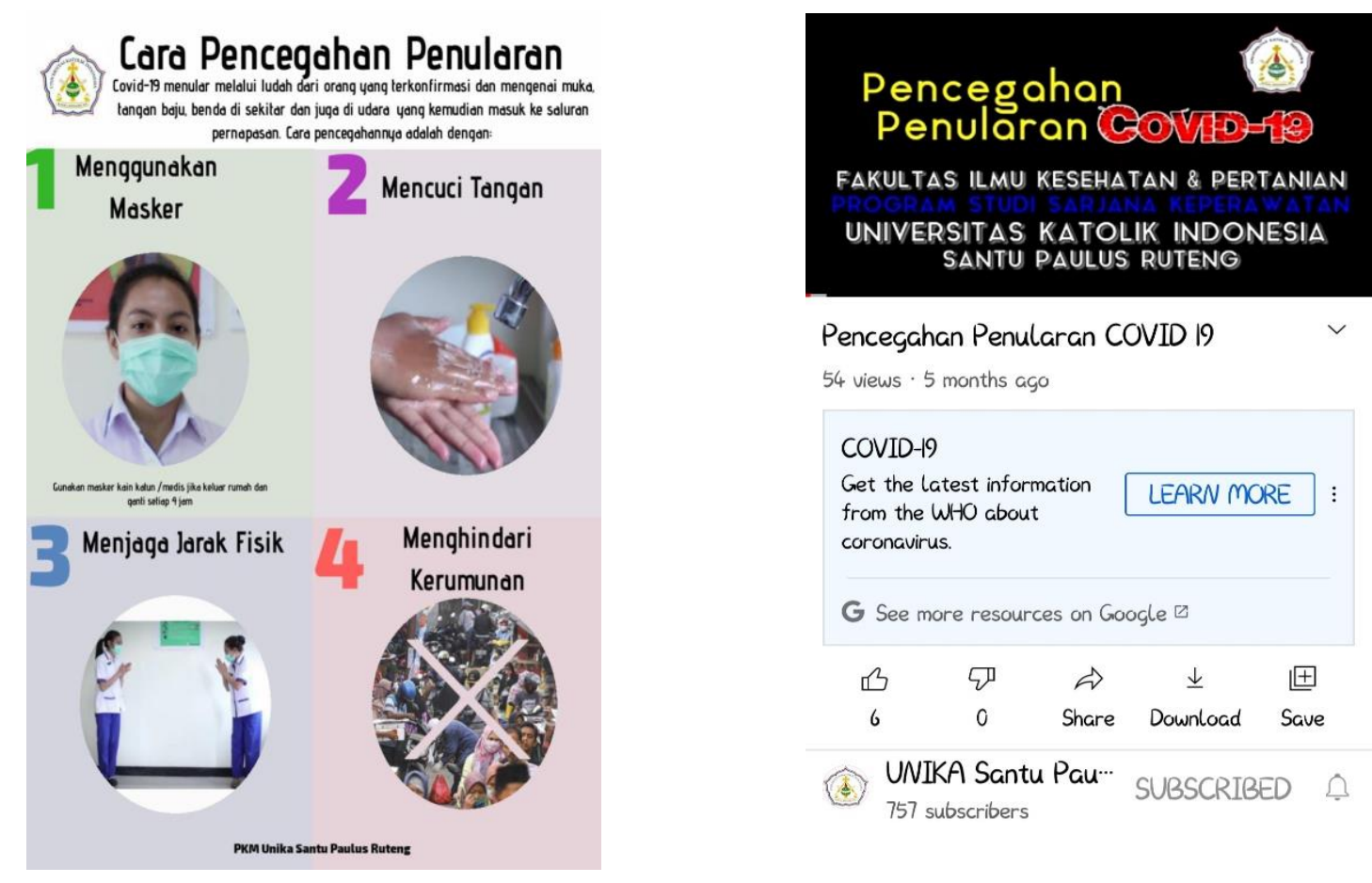

Pencegahan Penularan COVID 19

54 views 5 months ago

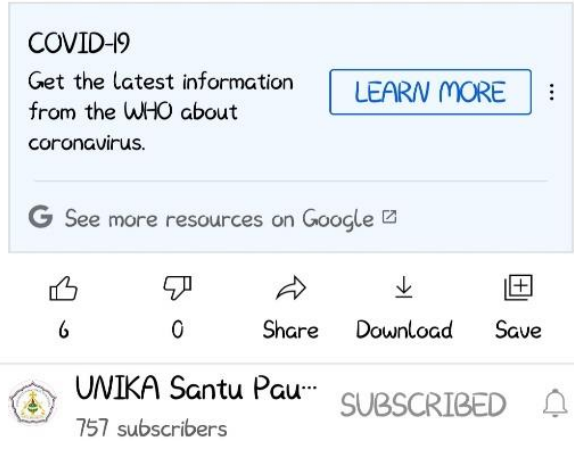

Gambar 3. Leaflet dan video edukasi

4. HASIL

Karakteristik Responden

Pengabdian Masyarakat ini diberikan kepada 160 orang masyarakat umum berusia 17 tahun ke atas. Pengabdian dilakukan selama 2 bulan dari bulan Desember 2020 - Februari 2021.

Table 2. Karateristik Responden $(n=160)$

\begin{tabular}{clcc}
\hline No. & \multicolumn{1}{c}{ karakteristik } & Total & $\begin{array}{c}\text { Persentase } \\
(\%)\end{array}$ \\
\hline 1. & Jenis Kelamin & & 55 \\
& $\begin{array}{l}\text { Perempuan } \\
\text { Laki-laki }\end{array}$ & 88 & 45 \\
\hline 2. & Usia & 72 & \\
& 17- 20 tahun & 21 & 13,1 \\
& 20 - 30 tahun & 116 & 72,5 \\
& 30 - 40 tahun & 23 & 14,4 \\
\hline 3. & Pendidikan & & \\
& a. SMA & 18 & 11.25 \\
& b. Perguruan Tinggi & 142 & 88.75 \\
\hline
\end{tabular}

Table 2 Menunjukkan bahwa partisipan paling banyak adalah laki-laki, berusia 20-30 tahun, dan pendidikan perguruan tinggi. 


\section{Perubahan Pengetahuan dan perilaku masyarakat setelah diberikan edukasi kesehatan}

Hasil pengabdian masyarakat dianalisis menggunakan metode quasiexperimental method pre and post without control group. Analisis perubahan pengetahuan dan perilaku setelah diberikan edukasi kesehatan melalui online dapat dilihat pada tabel di bawah

Tabel 3. Perubahan Pengetahuan dan perilaku masyarakat setelah diberikan edukasi kesehatan

\begin{tabular}{llccccc}
\hline Variabel & Intervention & $\mathrm{n}$ & Mean & SD & Min-Max & $\begin{array}{l}\boldsymbol{P} \\
\text { value }\end{array}$ \\
\hline Pengetahuan & Pre & 160 & 11,57 & 2,648 & $8-19$ & \multirow{2}{*}{0,002} \\
\cline { 2 - 6 } & Post & 160 & 17,23 & 1,794 & $13-21$ & \\
\hline Perilaku & Pre & 160 & 16,23 & 1,794 & $13-21$ & 0,001 \\
\cline { 2 - 6 } & Post & 160 & 21,03 & 1,286 & $16-21$ & \\
& & & & & &
\end{tabular}

Tabel 3 di atas menunjukkan bahwa terjadi peningkatan yang signifikan pada pengetahuan klien setelah dilakukan edukasi kesehatan secara online yaitu sebelum dilakukan rata-rata pengetahuan sebelum adalah 11,57 menjadi 17,23 setelah dilakukan. Selain itu terjadi juga peningkatan perilaku sebelum edukasi dari 16,23 menjadi 21,03.

\section{Pembahasan}

Sejak ditetapkan sebagai pandemik oleh World Health Organization (WHO) bulan Maret 2020, hingga kini belum ditemukan vaksin atau obat untuk COVID-19. WHO mengeluarkan perilaku pencegahan meliputi menjaga imunitas fisik dan psikologis, penggunaan masker, mencuci tangan, dan menghindari keamanan (WHO, 2020). Untuk mencegah penyebaran COVID-19 pemerintah telah mencanangkan program perlindungan dan pencegahan dengan cara memberikan peringatan, informasi tentang virus, cara mencegah, hingga melakukan lock down. Namun demikian masih banyak individu yang mengabaikan perilaku sehat ini sehingga penyebaran COVID-19 semakin meningkat. Sebelum diberikan edukasi, gambaran perilaku klien adalah 11,57 (rendah) dan setelah diberikan edukasi meningkat menjadi 17.23 (tinggi) Perilaku kesehatan dipengaruhi oleh beberapa faktor yaitu pengetahuan, kebiasaan, kepercayaan tentang kesehatan, dan lingkungan sosial (Gardner, 2020) selain itu usia, jenis kelamin, pengetahuan, status sosial ekonomi juga mempengaruhi perilaku kesehatan (Sutton, 2004). Penelitian sebelumnya menjelaskan faktor yang mempengaruhi rendahnya perilaku pencegahan COVID yaitu banyak orang yang merasa dirinya tidak memiliki risiko terkena penyakit tersebut, merasa tidak mampu dan malas melakukan perilaku pencegahan, dan kecemasan akibat berita tentang COVID-19 yang menyebabkan perilaku menghindar (Gardner, 2020) Oleh karena itu pemberian edukasi tidak hanya berfokus pada fisik tetapi juga psikososial.

Edukasi COVID-19 diberikan dengan cara memberikan pendidikan tentang meningkatkan imunitas fisik dan pencegahan penularan. Selain pemberian 
edukasi, partisipan juga dimotivasi untuk melakukan perilaku baru sebagai kebiasaan dengan bimbingan dan latihan mandiri selama 14 hari. Hasil dari pemberian edukasi menggunakan pendidikan kesehatan dan melakukan perilaku sehat sebagai kebiasaan menunjukkan adanya peningkatan sebesar 36\% pada perilaku individu dari perilaku sedang $(16,23)$ ke perilaku tinggi $(20.03)$. Pemberian edukasi dilakukan dengan menekankan bahwa COVID 19 merupakan penyakit yang berisiko tinggi dan hanya dapat dicegah dengan melakukan tindakan pencegahan yang dibuat seefektif mungkin. Individu juga diberi motivasi agar melakukan pencegahan tersebut. Hal tersebut sesuai dengan teori health belief model yaitu mengubah perilaku seseorang tidaklah semudah menyampaikan risiko kesehatan, berbagai penelitian mengungkapkan bahwa individu akan melakukan perubahan kesehatan jika percaya bahwa mereka memiliki risiko tinggi terkena penyakit yang memerlukan pencegahan, kondisi penyakit yang berat, disediakan langkah-langkah pencegahan yang efektif, dan percaya bahwa mereka mampu melakukan langkah-langkah pencegahan (Havigerová, 2019). Penelitian sebelumnya tentang edukasi COVID-19 menunjukkan adanya peningkatan pengetahuan $21.7 \%$ pengetahuan masyarakat setelah diberikan edukasi kesehatan (Pebriana a tal, 2021) Oleh karena itu dalam mengubah perilaku kesehatan tidak hanya diberikan pendidikan kesehatan tetapi juga motivasi untuk menjadikan perilaku sehat sebagai kebiasaan.

Pengetahuan merupakan faktor yang mempengaruhi perilaku, tetapi pengetahuan yang baik tidak serta merta mengubah perilaku hal yang lain yang mengubah perilaku adalah kepercayaan yang dianut tentang kesehatan dan juga kebiasaan (Arlinghaus \& Johnston, 2017) Penelitian sebelumnya mengungkapkan bahwa penerapan pendidikan dan kebiasaan untuk mengubah perilaku sehat individu dinilai mampu memberikan dampak perubahan yang cukup lama (Sutton, 2004). Hal tersebut karena kebiasaan dapat meningkatkan perilaku sehat individu secara permanen, karena perilaku yang muncul dari kebiasaan akan sulit diubah. Oleh karena itu untuk mengurangi penyebaran COVID 19 diperlukan cara yang mudah yaitu dengan meningkatkan pengetahuan dan menjadikan cara pencegahan sebagai kebiasaan yang dilakukan oleh individu setiap hari. Hal tersebut menjadikan perilaku pencegahan sebagai perilaku otomatis yang dilakukan individu.

\section{KESIMPULAN}

Kegiatan pengabdian masyarakat ini terdiri dari 3 pokok kegiatan yaitu (1) Pemberian edukasi tentang cara meningkatkan imunitas fisik dan pencegahan penularan (2) Latihan mandiri cara meningkatkan imunitas fisik dan mencegah penularan COVID-19 (3) Evaluasi hasil edukasi kesehatan dan latihan Manggarai. Setelah dilakukan edukasi dan latihan mandiri didapatkan bahwa terjadi peningkatan pengetahuan dari pengetahuan rendah ke pengetahuan tinggi dan perilaku dari perilaku sedang menjadi perilaku baik. Edukasi dan latihan mandiri dapat meningkatkan pengetahuan dan perilaku masyarakat. Oleh karena itu pemerintah dan tenaga kesehatan harus memberikan informasi tentang COVID-19 dan memotivasi masyarakat untuk melakukan perilaku pencegahan COVID-19 dan mengurangi penularan.

\section{Ucapan Terima Kasih}

Lembaga penelitian dan pengabdian masyarakat Universitas Katolik Indonesia Santu Paulus Ruteng untuk dukungan baik materi maupun non materi untuk sehingga kegiatan ini berjalan dengan lancar. 


\section{DAFTAR PUSTAKA}

Arlinghaus, K. R., \& Johnston, C. A. (2017). Advocating for Behavior Change. 12(2), 113-116. https://doi.org/10.1177/1559827617745479.

Benjamin Gardner. (2020). Making health habitual : the psychology of ' habitformation' and general practice. Health Behaviour Research, December, 664-666.

CDC. (2020). Symptoms of Coronavirus ( COVID-19). 316475.

Djalante, R., Lassa, J., Setiamarga, D., Sudjatma, A., Indrawan, M., Haryanto, B., Mahfud, C., Sabaruddin, M., Djalante, S., Ra, I., Adi, L., Ayu, G., Surtiari, K., \& Warsilah, H. (2020). Progress in Disaster Science Review and analysis of current responses to COVID-19 in Indonesia: Period of January to March 2020 «. 6. https://doi.org/10.1016/j.pdisas.2020.100091

Havigerová, J. M. (2019). One health behavior or many health-related behaviors? Psychology Research and Behavior Management, 23-30.

López-Bueno, R., Calatayud, J., Casaña, J., Casajús, J. A., Smith, L., Tully, M. A., Andersen, L. L., \& López-Sánchez, G. F. (2020). COVID-19 Confinement and Health Risk Behaviors in Spain. Frontiers in Psychology, 11(June), 110. https://doi.org/10.3389/fpsyg.2020.01426

Ningsih, O. S., Eka, A. R., \& Danal, P. H. (2021). Factors Predicting Adolescents ' Compliance on Covid-19 Prevention Protocols. Indonesian Nursing Journal of Education and Clinic (Injec), 6(1). https://doi.org/10.24990/injecv6i1.36

Pebriani, U., Ifan, M., Daldian, D., Pratama, S.A., Kheru, A., Rafie, R (2021). Penyuluhan Tentang Pengetahuan Dasar Covid-19 Pada Pasien Di Puskesmas Rawat Jalan Way Halim Kota Bandar Lampung. Jurnal kreativitas Pengabdian kepada Masyarakat. Vol 4. No. 3.

Sutton, S. (2004). Determinants of Health-Related Behaviours: Theoretical and Methodological Issues. 94-126.

WHO. (2020). Coronavirus disease 2019 ( COVID-19). 2019(April).

Worldmeter. (2021). Coronavirus Update (Live): 129,078,788 Cases and 2,820,205 Deaths from COVID-19 Virus Pandemic. 